\title{
Sustainable Finance and the 2030 Agenda: Investing to Transform the World
}

\author{
María Mar Miralles-Quirós*(D) and José Luis Miralles-Quirós (D)
}

Department of Financial Economics, University of Extremadura, 06006 Badajoz, Spain; miralles@unex.es

* Correspondence: marmiralles@unex.es

check for updates

Citation: Miralles-Quirós, M.M.; Miralles-Quirós, J.L. Sustainable Finance and the 2030 Agenda: Investing to Transform the World. Sustainability 2021, 13, 10505. https:/ / doi.org/10.3390/su131910505

Received: 18 September 2021 Accepted: 20 September 2021 Published: 22 September 2021

Publisher's Note: MDPI stays neutral with regard to jurisdictional claims in published maps and institutional affiliations.
On 25 September 2015, the member states of the United Nations approved an initiative in New York called "Transforming our world: the 2030 Agenda for Sustainable Development". This involved approving 17 Sustainable Development Goals (SDGs) to globally address crucial problems such as hunger, extreme poverty, disease, social inequality, climate change and environmental destruction, among others. The SDGs were, therefore, the foundation for an agenda for the next 15 years representing a global action plan for people, the planet and prosperity through international partnerships enabling sustainable development.

The concept of sustainable development was first adopted in 1987 in a report published by the United Nations, commonly known as the Brundtland Report [1], and was defined as "development that meets the needs of the present without compromising the ability of future generations to meet their own needs". This report pointed out the high environmental cost of global economic development policies and uncontrolled social progress and encouraged a rethink of these policies to reconcile and balance economic and social development with environmental sustainability.

Later, several conferences were held on this subject, such as the International Conference on the Human Environment in 1992 and the International Conference on Population and Development in 1994, among others [2,3]. However, it was in 2000 when the United Nations gave an important boost to sustainable development policies by approving the so-called Millennium Development Goals (MDGs) [4]. These were eight international goals that pursued targets such as the eradication of hunger and poverty, universal primary education, combating AIDS and other diseases and ensuring environmental sustainability, among others. The signatory countries committed themselves to working towards these goals for the next 15 years. However, the achievement of the Millennium Goals was partial and uneven in many countries, so the idea was to give a new impetus to the goals established.

Three years before the deadline set for the achievement of the Millennium Goals, at the United Nations Conference on Sustainable Development in 2012, also known as Rio+20, member states began work on updating the goals set at the Millennium Summit [5] with the aim of assessing what had been achieved so far and tackling the emerging challenges facing the world, mainly within the framework of the green economy, sustainable development, and eradicating poverty. A working group coming out of this conference carried out consultations for two years with all kinds of citizens, associations, scientists, academics, and representatives of the private sector, and there were debates at the intergovernmental level; this ultimately resulted in 17 new SDGs. It was clear that the collaboration of everyone at different levels would be required to achieve the new SDGs, including: (i) at the global level through cooperation from global leaders; (ii) at the local level through public policies and favorable laws; and (iii) through people, both at the individual and group level, such as members of civil societies, the media, and especially private companies [6].

It should be noted that the implementation of these goals is not mandatory. However, the United Nations has urged both the public and private sectors to adopt these targets 
to accelerate the transition to a sustainable economy. More precisely, the United Nations has stressed that it is essential for companies to be aware of the SDGs and incorporate them into their business policies, since, due to their strong impact on the population, the achievement of the goals is more feasible with their collaboration. Moreover, the United Nations points out that the role of investors is essential to achieve the SDGs, because their financial resources can help change the world [7].

In this context, this special issue focuses on the crucial role that the financial sector is expected to play in this framework. We are convinced that sustainable finance is an essential factor in this process. Moreover, the ways to contribute to this transformation are very diverse and include the provision of new financial products associated with these global goals, adapting existing financial tools to help companies achieve the SDGs, and the awareness of all those who work in financial institutions or participate in financial markets as investors or as applicants for financing.

In this environment of awareness about and adaptation to the new reality and these new goals, academia has much to contribute. When researchers include these goals in their research, they are helping to raise awareness in society in general and among those working in the financial sector in particular, who can contribute to this whole process [8,9]. It is therefore hugely important for academia to provide financial tools and viable investment strategies, greater knowledge about the advantages of investing in financial assets associated with the SDGs, and ways of measuring the value created for a country's economy or a company if they contribute to the SDGs, among other aspects.

For this reason, we decided to edit this special issue and encouraged other researchers to submit the research they were conducting on: sustainable investment decisions and asset allocation; the performance of bonds, mutual funds, indices or exchange-traded funds (ETFs) associated with the SDGs; the financial risks and opportunities caused by SDG challenges, such as climate change and the transition to clean energy; the importance of microfinance or foreign direct investment in developing countries; or any other research related to the role of the financial markets, financial institutions or other participants in the financial sector in achieving the SDGs.

This resulted in the publication of eight articles with different aims. This is a sign that sustainable finance can play a very diverse role in achieving the SDGs. Three of the articles relate to socially responsible investment (SRI). These are the works of Boumda et al. [10], Vilas et al. [11] and De Sousa Gabriel et al. [12]. Two other papers focus on the use of the real options methodology to solve financial problems associated with the achievement of a particular SDG. These are the works of Cruz-Rambaud et al. [13] and Rodrigo-Gonzalez et al. [14]. Finally, there are three miscellaneous papers, those of Kocornik-Mina et al. [15], Sseruyange and Klomp et al. [16] and Szymanska [17], that analyze, respectively, the practices of value-based banking in achieving social impact, the role of microfinance in mitigating the consequences of natural disasters and the contribution of the 27 member countries of the European Union to achieving SDG 10, which is related to reducing inequalities.

Regarding the first group of papers, it should be noted that SRI is no longer an alternative type of investment. More and more stock market investors are taking sustainability criteria into account when making their investment decisions. Proof of this is that the US Forum for Sustainable and Responsible Investment has indicated that in 2020, one out of every three dollars of the total value of assets under professional management (51.4 trillion US dollars) was allocated to investment with sustainability criteria in the North American stock markets [18].

In this context, Boumda et al. [10] analyze the so-called "disposition effect" over the period 2005-2020 in a sample of US socially responsible mutual funds, as well as in a sample of US conventional mutual funds with similar characteristics in terms of age, size and overall category. As the authors point out, professional managers of socially responsible investment funds are expected to respect the objectives of the investors who trust them. As a result, they are not expected to behave in the same way as professional managers 
of conventional mutual funds who are often driven by their emotions when reacting to changes in the prices of the shares included in their portfolio. However, their overall results indicate that there are no significant differences in the behavior of socially responsible and conventional fund managers. Therefore, they argue that investors who use this financial tool are predictably not achieving the non-financial objectives they were pursuing.

These results are not positive. However, it should also be noted that, due to increasing investor awareness of social and environmental issues, individual investment is becoming increasingly widespread. The emergence of sustainability indices, which serve as benchmarks for these investors, is contributing to this. The analysis of these indices is the focus of the other two articles published in relation to SRI. However, these two articles do not follow the common lines of research focused on analyzing the financial performance of these indices $[19,20]$ or the permanence of companies included in the composition of these indices [21,22]. Instead, they address two novel aspects.

Vilas et al. [11] compare the composition of sustainable indices with the composition of conventional indices using the so-called "sustainability share". Specifically, they analyse three conventional indices in the FTSE family (belonging to the financial information provider Financial Times Stock Exchange) and their FTSE4Good counterparts over the period 2008-2019. More precisely, they study whether passive investors in social responsibility meet their non-financial expectations. However, they observe that the sustainability share has been decreasing over time. Therefore, the composition of the two types of indexes has become more similar, and this raises the question of whether these investors are achieving their non-financial expectations. Consequently, these authors propose requiring stock index providers to change the weighting method used for sustainable indices to obtain a significantly different composition from that of their conventional counterparts.

De Sousa Gabriel et al. [12] show that SRI is a very broad concept that includes different types of investment, such as green and environmental investment. These authors compare green investment with oil-based investment. They point out that, despite all the efforts made by the public and private sectors to minimize economic dependence on oil, this commodity is still dominant among the world's energy needs and changes in its price have economic and environmental effects. Therefore, they fill a gap in the financial research by analyzing, for the period from January 2009 to November 2020, both the short- and long-term relationship between the price of oil and the environmental stock market indices developed and distributed by Morgan Stanley Capital International (MSCI) related to alternative energy, clean technology, green building, sustainable water and pollution prevention. Specifically, they find that the relationship between oil prices and the performance of environmental indices is limited to periods of turbulence and no lasting equilibrium relationship is observed. These results may have important practical implications. In particular, the results encourage investors to diversify their investments by considering both types of assets if they have a long-term investment strategy.

Regarding the second group of papers published in this special issue, we can highlight the work of Cruz-Rambaud et al. [13]. These authors document the important role that the civil aeronautical industry can play in the coming years in the transition to clean energy by contributing to greener and more sustainable air transport. This can be achieved by building aircraft that use environmentally friendly fuels. However, this entails large-scale investment projects. These authors propose using a methodology based on real options instead of the traditional net present value (NPV) to evaluate these investment projects. This is a very interesting article, and its practical application is straightforward. In the same vein is the work of Rodrigo-González et al. [14]. These authors also propose the methodology of real options to quantify the value that the circular economy generates in companies instead of the traditional NPV. The main contribution of this research, as the authors point out, is to provide a quantitative approach to valuing circularity in a general context and one that can be adapted to many very specific situations for different companies involved with the CE. 
Finally, we focus on the work of Kocornik-Mina et al. [15], Sseruyange and Klomp et al. [16] and Szymanska [17]. Kocornik-Mina et al. [15] select a sample of 30 banks that are pioneers in social impact and members of the Global Alliance for Banking on Values (GABV). Specifically, they analyze how these financial institutions define, design, implement, monitor and scale social impact in their companies. This paper contributes to the scarce literature on social impact assessment in the financial sector through an in-depth analysis of the best practices carried out by these banks. The results obtained in this research are compelling and indicate that the more sustainable a country's financial model is, the greater its contribution to the achievement of the SDGs. Moreover, these results can help other financial institutions to design effective frameworks and practices in this area.

In addition, Sseruyange and Klomp et al. [16] discuss the important role that microfinance institutions (MFIs) can play in mitigating the adverse macroeconomic consequences of natural disasters that are often directly associated with climate change. These authors document the importance of a country's financial development in coping with the economic consequences of a natural disaster and how developing countries are more vulnerable because they have limited access to the formal banking system. They analyze the role of microfinance in 80 developing countries using information obtained from the global webbased microfinance information platform. The results of their research show that access to MFI lending facilities mitigates much of the negative effect of a natural disaster. However, they also note that this evidence depends on the organizational structure, profitability, legal system, age, and number of clients of these financial institutions. In short, this is an important study in the field of research into sustainable economic growth.

Finally, we highlight the work carried out by Szymanska [17]. In the first part of her research, this author analyses the socio-economic conditions of the EU27 in relation to the reduction of social inequalities during the period 2010-2019 and, therefore, the EU's contribution over these years to the achievement of SDG 10 (reducing inequality within and between countries). In the second part of the paper, she investigates the (dis)similarities between the different EU member states with respect to levels of inequality, as well as the progress of these member states in reducing inequalities between them. For the first part of the research, she uses a set of indicators extracted from the Eurostat database, and, for the second part, she uses a set of additional variables that may affect the levels and dynamics of inequalities between and within countries. The main results obtained from this study indicate that the EU has been able to make progress in reducing inequalities between countries, although income inequalities within countries not only persist but have widened in recent years. These findings suggest that further research is needed in these areas, as well as on the possible contributions of sustainable finance to mitigate these inequalities.

Finally, we should refer to the latest developments in the evolution of the achievement of the SDGs globally and the role of sustainable finance in them. Firstly, we can mention that, at the United Nations summit held in 2019, world leaders pledged to boost investment in the SDGs from 2020 onwards by declaring the period 2020-2030 as "The Decade of Action". They specifically pledged to address the problems of climate change and to reduce the deep social inequalities caused by the lack of resources faced by millions of people, as both issues have become the main threat to the achievement of the SDGs [23]. However, we now also have to consider the impact of the COVID-19 pandemic, which is currently holding back many of the aspirations for achieving the SDGs by 2030.

Therefore, this decade needs major changes to achieve the 2030 Agenda, and the role of the financial sector and research into sustainable finance is key to achieving it. Future research should be aimed at analyzing the role of the financial sector in the fight against climate change and inequality, which are the most important challenges today. However. we should not forget other aspects such as encouraging investment in companies that contribute to the achievement of these challenges. Therefore, following previous studies [24-27], we should continue researching SRI by analyzing the levels of risk and the reaction in the markets to situations of uncertainty in this type of investment, among other aspects. 
Author Contributions: This work is an outcome of the joint reflections of M.M.M.-Q. and J.L.M.-Q. All authors have read and agreed to the published version of the manuscript.

Funding: M.M.M.-Q. and J.L.M.-Q. recognize and are grateful for the financial support received from Junta de Extremadura under the VI Action Plan for Research and Development 2017/20 through the GIMAF research group (reference GR18022).

Institutional Review Board Statement: Not applicable.

Informed Consent Statement: Not applicable.

Data Availability Statement: Not applicable.

Acknowledgments: The authors would like to thank the assistant editor, Simi Wang, for her careful support and suggestions. We would also like to thank all the academics who have collaborated in this Special Issue with their research and who have contributed to the discussion about the role of sustainable finance in achieving the SDGs.

Conflicts of Interest: The authors declare no conflict of interest.

\section{References}

1. Brundtland, G.H. Our common future-Call for action. Environ. Conserv. 1987, 14, 291-294. Available online: http://un-documents. net/our-common-future.pdf (accessed on 8 September 2021). [CrossRef]

2. United Nations International Conference on Environment and Development. 1992. Available online: https://www.un.org/en/ conferences/environment/rio1992 (accessed on 8 September 2021).

3. United Nations International Conference on Population and Development. 1994. Available online: https://www.un.org/en/ conferences/population/cairo1994 (accessed on 8 September 2021).

4. United Nations. Millennium Declaration, United Nations 2020. Document A/RES/55/2. Available online: https://www. un.org/en/development/desa/population/migration/generalassembly/docs/globalcompact/A_RES_55_2.pdf (accessed on 8 September 2021).

5. United Nations International Conference on Sustainable Development. 2012. Available online: https://www.un.org/en/ conferences/environment/rio2012 (accessed on 8 September 2021).

6. United Nations Sustainable Goals. Take Action for the Sustainable Development Goals. Available online: https://www.un.org/ sustainabledevelopment/sustainable-development-goals / (accessed on 8 September 2021).

7. United Nations. Beyond the Business Case: The Strategic Role of the Private Sector in Transforming the Real Economy towards an Inclusive, Green and Circular Future. In Department of Economics and Social Affairs Working Paper No. 169. Available online: https://www.un.org/esa/desa/papers/2020/wp169_2020.pdf (accessed on 8 September 2021).

8. Miralles-Quirós, J.L.; Miralles-Quirós, M.M. Are alternative energies a real alternative for investors? Energy Econ. 2019, 78, 535-545. [CrossRef]

9. Miralles-Quirós, J.L.; Miralles-Quirós, M.M.; Nogueira, J.M. Sustainable development goals and investment strategies: The profitability of using five-factor Fama-French alphas. Sustainability 2020, 12, 1842. [CrossRef]

10. Boumda, B.; Duxbury, D.; Ortiz, C.; Vicente, L. Do Socially Responsible Investment Funds Sell Losses and Ride Gains? The Disposition Effect in SRI Funds. Sustainability 2021, 13, 8142. [CrossRef]

11. Vilas, P.; Andreu, L.; Sarto, J.L. The Convergence between Sustainability and Conventional Stock Indices. Are We on the Right Track? Sustainability 2021, 13, 7613. [CrossRef]

12. De Sousa Gabriel, V.M.; Miralles-Quirós, M.M.; Miralles-Quirós, J.L. Shades between Black and Green Investment: Balance or Imbalance? Sustainability 2021, 13, 5024. [CrossRef]

13. Cruz Rambaud, S.; López Pascual, J.; Meléndez Rodríguez, J.C. Sustainability in the Aerospace Sector, a Transition to Clean Energy: The E2-EVM Valuation Model. Sustainability 2021, 13, 6717. [CrossRef]

14. Rodrigo-González, A.; Grau-Grau, A.; Bel-Oms, I. Circular Economy and Value Creation: Sustainable Finance with a Real Options Approach. Sustainability 2021, 13, 7973. [CrossRef]

15. Kocornik-Mina, A.; Bastida-Vialcanet, R.; Eguiguren Huerta, M. Social Impact of Value-Based Banking: Best Practices and a Continuity Framework. Sustainability 2021, 13, 7681. [CrossRef]

16. Sseruyange, J.; Klomp, J. Natural Disasters and Economic Growth: The Mitigating Role of Microfinance Institutions. Sustainability 2021, 13, 5055. [CrossRef]

17. Szymanska, A. Reducing Socioeconomic Inequalities in the European Union in the Context of the 2030 Agenda for Sustainable Development. Sustainability 2021, 13, 7409. [CrossRef]

18. US SFI Foundation: The Forum for Sustainable and Responsible Investment. 2020 Report on U.S. Sustainable and Impact Investing Trends. Available online: https:/ / www.ussif.org/files/US\%20SIF\%20Trends\%20Report\%202020\%20Executive\%20Summary.pdf (accessed on 8 September 2021).

19. Cunha, F.A.F.S.; Oliveira, E.M.; Orsato, R.J.; Klotzle, M.C.; Oliveira, F.L.C.; Caiado, R.G.G. Can sustainable investments outperform traditional benchmarks? Evidence from global stock markets. Bus. Strategy Environ. 2020, 29, 682-697. [CrossRef] 
20. Sharma, G.D.; Tiwari, A.K.; Talan, G.; Jain, M. Revisiting the sustainable versus conventional investment dilemma in COVID-19 times. Energy Policy 2021, 112467. [CrossRef]

21. Ziegler, A. Is it beneficial to be included in a sustainability stock index? A panel data study for European firms. Environ. Resour. Econ. 2012, 52, 301-325. [CrossRef]

22. Miralles-Quirós, M.M.; Miralles-Quirós, J.L.; Arraiano, I.G. Sustainable development, sustainability leadership and firm valuation: Differences across Europe. Bus. Strategy Environ. 2017, 26, 1014-1028. [CrossRef]

23. United Nations Climate Action Summit 2019. Available online: https:/ /www.un.org/en/climatechange/2019-climate-actionsummit (accessed on 8 September 2021).

24. Miralles-Marcelo, J.L.; Miralles-Quirós, J.L.; Miralles-Quirós, M.M. Intraday linkages between the Spanish and the US stock markets: Evidence of an overreaction effect. Appl. Econ. 2010, 42, 223-235. [CrossRef]

25. Miralles-Marcelo, J.L.; Miralles-Quirós, M.M.; Miralles-Quirós, J.L. Asset pricing with idiosyncratic risk: The Spanish case. Int. Rev. Econ. Financ. 2012, 21, 261-271. [CrossRef]

26. Ghulame, R.; Ali, A.K.; Shoaib, A.; Muhammad, N. Are ESG Stocks Safe-Haven during COVID-19? SSRN Electron. J. 2021. Available online: https:/ / papers.ssrn.com/sol3/papers.cfm?abstract_id=3779430 (accessed on 8 September 2021).

27. Chiappini, H.; Vento, G.; De Palma, L. The Impact of COVID-19 Lockdowns on Sustainable Indexes. Sustainability 2021, $13,1846$. [CrossRef] 